\title{
PERMINTAAN PERJALANAN ANGKUTAN UMUM MASSAL KOTA SURABAYA
}

\section{MASS TRANSPORTATION TRAVEL DEMAND OF SURABAYA CITY}

\author{
Djoko Prijo Utomo \\ Pusat Teknologi Industri dan Sistem Transportasi \\ Deputi Teknologi Industri Rancang Bangun dan Rekayasa - BPPT \\ Gedung Teknologi 2 BPPT Lantai 3, Kawasan PUSPIPTEK, Tangerang Selatan \\ Telp: 021-75875938; Fax. 021-75875946 \\ Email:djokoprijo@yahoo.com
}

\begin{abstract}
Abstrak
Sebagaimana kota-kota metropolitan di dunia, kemacetan menjadi permasalahan utama dalam bidang transportasi perkotaan. Kemacetan terjadi pada umumnya karena ketidakseimbangan antara penyediaan (supply) dengan permintaan (demand). Usaha untuk menekan jumlah kendaraan di jalan, salah satunya, adalah dengan mempromosikan pengunaan angkutan umum kota. Oleh karena itu diperlukan sebuah perencanaan penyediaan fasilitas angkutan umum. Untuk memperkirakan permintaan angkutan umum dibangun model lalu lintas yang mereplikakan bangkitan, pola dan pembebanan perjalanan. Hasil kalibrasi model distribusi perjalanan menggunakan gravity model diperoleh fungsi impedance yang terbentuk dari fungsi waktu perjalanan dengan faktor $\beta$ sebesar 0.063 . Perbedaan mean trip length model (dengan observed adalah $-5,4 \%$. Mean trip length (MTL) model dengan angkutan umum adalah 17,04 menit dan hasil survai 18,02 menit. Model yang terbangun validasinya cukup baik dengan indikator $\mathrm{R}^{2}$ terhadap data observed sebesar 0,88 . Hasil dari seluruh tahapan proses pemodelan diperoleh total permintaan perjalanan dengan angkutan umum tahun 2030 diperkirakan mencapai 67.800.434 penumpang/tahun.
\end{abstract}

Kata kunci: angkutan umum masal, distribusi perjalanan, gravity model.

\begin{abstract}
As metropolitan cities in the world, congestion becomes a major problem in the field of urban transport. Congestion occurs generally due to an imbalance between supplyand demand. Attempts to reduce the number of vehicles on the road, one of which, is to promote the utilization of public transport. Therefore we need a plan for the provision of public transport facilities. To estimate the demand for public transport, it is built transport model which is replicating the trip generation, trip distribution and trip assignment. The results of the trip distribution model calibration using a gravity model obtained impedance function which is formed from travel time functionby a $\beta$ factor of 0.063 . Mean trip length difference between model and observed is equal -5,4\%.Mean trip length (MTL) model utilizing public transportsis about 17.04 minutes whereasMTL resulted from traffic survey is about 18.02 minutes. The model validation is quite well with observed data by showing the $R^{2}$ indicatorof about 0.88 . The results fromall stages modeling process obtained total travel demand by public transport in the year of 2030 is estimated at about 67,800,434 passengers/year.
\end{abstract}

Keywords: mass transit, trip distribution, gravity model.

Diterima (received) : 19 Juni 2013, Direvisi (reviewed) : 22 Juni 2013,

Disetujui (accepted) : 12 Juli 2013 


\section{PENDAHULUAN Latar Belakang}

Jumlah penduduk Kota Surabaya pada tahun 2011 mencapai angka 3.024.321 jiwa sehingga dikategorikan sebagai salah satu kota metropolitan di Indonesia. Sebagaimana kota-kota metropolitan di dunia maka kemacetan menjadi permasalahan utama dalam bidang transportasi perkotaan. Kemacetan terjadi pada umumnya karena ketidak seimbangan antara penyediaan (supply) dengan permintaan (demand). Keterbatasan penyediaan ini disebabkan berbagai faktor antara lain keterbatasan ruang dan keterbatasan kemampuan pemerintah dalam mendanai pembangunan infrastruktur (jaringan jalan) perkotaan. Pada sisi lain permintaan transportasi terus tumbuh sejalan dengan pertumbuhan perekonomian kota. Permintaan transportasi di Kota Surabaya tidak semata karena pertumbuhan Kota Surabaya melainkan juga karena adanya dan semakin berkembangnya kota-kota disekitarnya, seperti Kabupaten Gresik, Kabupaten Bangkalan, Kabupaten Mojokerto, Kota Mojokerto, Kabupaten Sidoarjo, dan Kabupaten Lamongan yang sering dikenal sebagai Kawasan Metropolitan Gerbangkertasusila.

Usaha menekan jumlah kendaraan di jalan, salah satunya, adalah dengan mengarahkan orang untuk mau beralih ke angkutan umum, dimana pada saat yang sama, sistem angkutan umum ditata sedemikian sehingga menjadi sangat menarik untuk digunakan. Ke depan, suka tidak suka, dengan keterbatasan ruang kota untuk pengembangan jaringan jalan, pemerintah harus menyediakan sistem angkutan umum massal cepat untuk mengakomodasi meningkatnya permintaan perjalanan di dalam kota dan daerah sekitar.

Untuk memprakirakan kebutuhan angkutan umum masal dan menentukan rute pelayanannya, salah satu tahapannya membutuhkan sebuah model distribusi perjalanan yang dapat mereplikakan asal dan tujuan perjalanan penduduk kota yang akan digunakan untuk tahap pembebanan perjalanan (traffic/transit assignment).

Model distribusi perjalanan yang digunakan dalam penelitian ini adalah model gravity dengan fungsi impedan menggunakan fungsi exponensial' ${ }^{1}$ dari parameter waktu perjalanan. Pemilihan waktu perjalanan sebagai fungsi impedan karena umumnya di daerah kota besar pemilihan rute perjalanan sangat dipengaruhi oleh waktu perjalanan dibandingkan jarak perjalanan. Dalam memilih lintasan perjalanan, jarak yang lebih pendek belum tentu memberikan waktu perjalanan yang lebih singkat.

\section{Maksud dan Tujuan Penelitian}

Maksud penelitian adalah untuk mendapatkan model distribusi perjalananyang dikelompokkan berdasarkan moda yang digunakan oleh penduduk di Kota Surabaya.

Tujuan penelitian adalah untuk mengkalibrasi data lapangan menjadi persamaan matematis model distribusi perjalanan yang dapat mereplikakan kondisi lapangan sebagai salah satu tahap dalam analisa permintaan perjalanan untuk angkutan umum masal kota Surabaya.

\section{BAHAN DAN METODE}

Dalam melakukan analisis pemodelan maka hal utama yang perlu didefinisikan adalah menentukan daerah kajian studi yaitu suatu daerah geografis yang didalamnya terletak semua zona asal dan zona tujuan yang diperhitungkan dalam model kebutuhan akan transportasi. Sebuah zona mempunyai sebuah pusat zona (centroid). Pusat zona dianggap sebagai tempat atau lokasi awal pergerakan lalulintas dari zona tersebut dan akhir pergerakan lalulintas yang menuju ke zona tersebut.

Pada masing-masing zona diperlukan data yang mempunyai pengaruh terhadap pola perjalanan, antara lain seperti: letak geografis, tata guna lahan, jumlah penduduk, tingkat pendapatan masyarakat, kepemilikan kendaraan dan ketersediaan akses dari masing-masing zona.

Letak geografis zona akan menentukan asal dan tujuan perjalanan, tata guna lahan akan memberikan indikasi kepada jumlah tarikan perjalanan (trip attraction), jumlah penduduk akan memberikan pengaruh kepada jumlah pelaku perjalanan (trip production), tingkat pendapatan akan mempengaruhi tingkat kemampuan dalam melakukan perjalanan, kepemilikan kendaraan akan memberikan kemudahan dalam melakukan perjalanan, sedangkan ketersediaan akses akan menentukan rute yang akan dipilih.

Dalam membagi wilayah menjadi zona-zona yang lebih kecil perlu adanya dasar pembagian zona yang harus dipertimbangkan adalah sebagai berikut ${ }^{2}$ : 
1. Keseragaman tata guna lahan

Keseragaman penggunaan lahan akan menjadi tolok ukur dalam usaha membagi wilayah menjadi beberapa zona. Hal ini dilakukan untuk mengetahui karakteristik perjalanan tiap-tiap zona pada kondisi penggunaan lahan tertentu seperti zona dengan penggunaan lahan untuk industri, perumahan, pariwisata, jasa komersial, fasilitas umum, perkantoran, pertanian/perikanan, hutan lindung dan sebagainya. Seperti diketahui bahwa lahan untuk industri akan menghasilkan jumlah perjalanan yang berbeda dengan lahan yang digunakan untuk jasa komersial maka sebaiknya pembagian zona didasarkan pada keseragaman tata guna lahan sehingga memudahkan dalam proses perhitungan bangkitan perjalanan.

2. Ketersediaan akses

Ketersediaan akses merupakan faktor penting dalam pembagian zona karena dengan adanya akses dari dan ke zona lainnya akan memberikan pengaruh terhadap hubungan antar zona sehingga timbul bangkitan perjalanan antara zona satu dengan zona lainnya.

\section{Ketersediaan data}

Pada setiap zona perencanaan diperlukan beberapa data sebagai bahan analisis. Oleh sebab itu pembagian zona harus mempertimbangkan ketersediaan data yang telah dibuat oleh pihak atau intansi tertentu sebagai basis pengumpulan data. Sebagai contoh adalah data tentang kependudukan, tenaga kerja, kepemilikan kendaraan dan lain-lain yang tersedia pada tiap-tiap kecamatan dan kelurahan/desa sehingga perlu dipertimbangkan pembagian zona kecil atas dasar pembagian wilayah administrasi.

\section{Keseragaman luas area}

Luas antara satu zona dengan zona lainnya yang berada di dalam derah kajian sedapat mungkin diupayakan tidak berbeda terlalu jauh. Hal tersebut agar bangkitan perjalanan yang dibangkitkan oleh tiap zona tersebut nilainya tidak berbeda jauh antara satu zona dengan zona lainnya.

Dengan dasar pertimbangan pembagian zona seperti diuraikan sebelumnya, maka untuk kegiatan penelitian ini Wilayah studi dipersiapkan untuk dibagi menjadi zonazona kecil berbasis pada wilayah kelurahan. Hal ini dilakukan dengan maksud agar mudah mendapatkan data-data tentang kondisi setiap zona lalu lintas, antara lain tentang kependudukan.
Pembagian zona tersebut disajikan pada Tabel 1 dan Gambar 1.

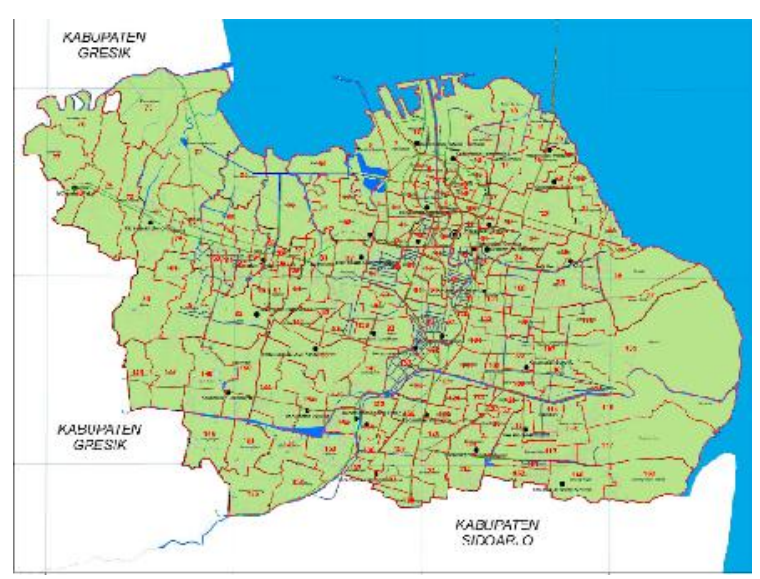

Gambar 1.

Zona Lalu lintas di Kota Surabaya

Setiap zona membutuhkan data penduduk yang sangat penting dalam proses pengembangan model baik mulai dari pengembangan model bangkitan perjalanan sampai dengan model distribusi perjalanan.

Untuk keperluan model dari sisi penyediaan (supply side), disusun data-data tentang kondisi jalan $^{5}$ (link) dari sistem jaringan jalan di Kota Surabayayang berisi informasi tentang panjang, jumlah lajur per jalur, arah arus, kapasitas jalur, fungsi volume dan kelambatan (volume delay function) serta moda yang dapat melalui jalan tersebut. Oleh karena itu data tentang kondisi jaringan jalan perlu diketahui. Jaringan jalan kota selanjutnya dibangun ke dalam alat bantu perangkat lunak seperti terlihat pada Gambar 2.

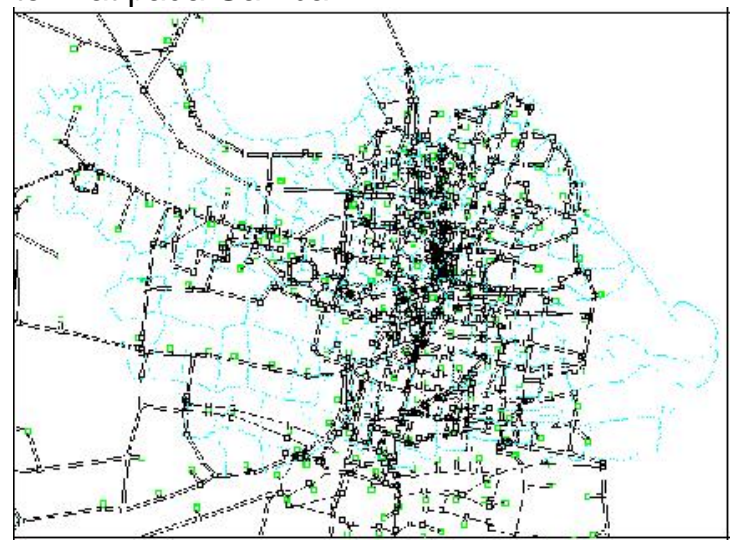

Gambar 2.

Komputerisasi Jaringan Jalan

Dari sisi permintaan (demand side), pola perjalanan penduduk kota Surabaya yang akan dimodelkan diperoleh dengan menggunakan teknik wawancara ke rumah tangga (home interview survey). Jumlah rumah tangga yang disurvei adalah sekitar $1 \%$ dari populasi jumlah rumah tangga kota Surabaya atau sekitar 7.631 rumah tangga. 
Tabel 1.

Zona Lalu Lintas

\begin{tabular}{|c|c|c|c|c|c|c|c|}
\hline Zona & Kelurahan & Zona & Kelurahan & Zona & Kelurahan & Zona & Kelurahan \\
\hline 1 & $\begin{array}{l}\text { Krembangan } \\
\text { Selatan }\end{array}$ & 43 & Genteng & 85 & Sonokwijenan & 125 & Margorejo \\
\hline 2 & $\begin{array}{l}\text { Selatan } \\
\text { Kemayoran }\end{array}$ & 44 & Kapasari & 86 & Putat Gede & 126 & $\begin{array}{l}\text { Jemur } \\
\text { Wonosari }\end{array}$ \\
\hline 3 & Perak Barat & 45 & Ketabang & 87 & Simomulya & 127 & Siwalankerto \\
\hline 4 & Dupak & 46 & Peneleh & 88 & Petemon & 128 & Wonokromo \\
\hline 5 & Morokrembangan & 47 & Alun-Alun & 89 & Sawahan & 129 & Jagir \\
\hline 6 & Bongkaran & 48 & $\begin{array}{l}\text { Contong } \\
\text { Bubutan }\end{array}$ & 90 & Banyu Urip & 130 & Ngagel \\
\hline 7 & Nyamplungan & 49 & Gundih & 91 & Putat Jaya & 131 & Ngagel Rejo \\
\hline$t$ & Krembangan & 49 & Guntain! & 92 & Kupang Krajan & 132 & Darmo \\
\hline 8 & Utara & 50 & Jepara & 93 & Pakis & 133 & Sawung Galing \\
\hline 9 & Perak Timur & 51 & Tembok Dukuh & 94 & Tegalsari & 134 & Jambangan \\
\hline 10 & Perak Utara & 52 & Asemrowo & 95 & D.R. Sutomo & 135 & Karah \\
\hline 11 & Ampel & 53 & Genting & 96 & Kedungdoro & 136 & Kebonsari \\
\hline 12 & Pegirian & 54 & Kalianak & 97 & Keputran & 137 & Pagesangan \\
\hline 13 & Wonokusumo & 55 & Greges & 98 & Wonorejo & 138 & Dukuh Pakis \\
\hline 14 & Ujung & 56 & Tambak Langon & 99 & Gubeng & 139 & Dukuh Kupang \\
\hline 15 & Sidotopo & 57 & Gedangasin & 100 & Mojo & 140 & Gunung Sari \\
\hline 16 & $\begin{array}{l}\text { Tanah Kali } \\
\text { Kedinding }\end{array}$ & 58 & Tandes Lor & 101 & Airlangga & 141 & $\begin{array}{l}\text { Pradah } \\
\text { Kalikendal }\end{array}$ \\
\hline 17 & Sidotopo Wetan & 59 & Gadel & 102 & Kertajaya & 142 & Wiyung \\
\hline 18 & Bulak Banteng & 60 & Tandes Kidul & 103 & Baratajaya & 143 & Jajar Tunggal \\
\hline 19 & Tambak Wedi & 61 & Tubanan & 104 & Pucang Sewu & 144 & Babadan \\
\hline 20 & Kedung Cowek & 62 & Karangpoh & 105 & Keputih & 145 & Balas Krumprik \\
\hline 21 & Komplek Kenjeran & 63 & Balongsari & 106 & Gebang Putih & 146 & Bangkingan \\
\hline 22 & Kenjeran & 64 & Bibis & 107 & Klampis Ngases & 147 & Jeruk \\
\hline 23 & Bulak & 65 & Manukan Kulon & 108 & Menur & 148 & Lakarsantri \\
\hline 24 & Sukolilo & 66 & Buntaran & & & & \\
\hline 25 & Mulyorejo & 67 & $\begin{array}{l}\text { Manukan } \\
\text { Wetan }\end{array}$ & 109 & Jangkungan & 149 & Lidah Kulon \\
\hline 26 & Manyar & 68 & Banjar Sugihan & 110 & Semolowaru & 150 & Lidah Wetan \\
\hline 27 & $\begin{array}{l}\text { Sabrangan } \\
\text { Kejawen Putih } \\
\text { Tambak }\end{array}$ & 69 & Kandangan & 111 & $\begin{array}{l}\text { Semampir } \\
\text { Kali Rungkut }\end{array}$ & 151 & Sumur Welut \\
\hline 28 & Kalisari & 70 & Klakah Rejo & 113 & Rungkut Kidul & 153 & Kebraon \\
\hline 29 & Dukuh Sutorejo & 71 & Sememi & 114 & Kedung Baruk & 154 & Kedurus \\
\hline 30 & Kalijudan & 72 & $\begin{array}{l}\text { Tambakoso } \\
\text { Wilangun }\end{array}$ & 115 & Panjaringan Sari & 155 & Warugunung \\
\hline 31 & Tambak Sari & 73 & Romo Kalisari & 116 & Wonorejo & 156 & Ketintang \\
\hline 32 & Ploso & 74 & Pakal & 117 & Medokan Ayu & 157 & Menanggal \\
\hline 33 & Gading & 75 & Babat Jerawat & 118 & Kutisari & 158 & $\begin{array}{l}\text { Dukuh } \\
\text { Menanggal }\end{array}$ \\
\hline 34 & Pacar Kembang & 76 & Tambak Dono & 119 & Kendangsari & 159 & Gayungan \\
\hline 35 & Rangkah & 77 & Sumber Rejo & 120 & Tanggilis Mejoyo & 160 & Gunung Anyar \\
\hline 36 & Pacar Keling & 78 & Benowo & 121 & Paniang Jiwo & 161 & Rungkut \\
\hline 37 & Simokerto & 79 & Sambi Kerep & & & & Tengah \\
\hline 38 & Kapasan & 80 & Made & 122 & Prapen & 162 & Menanggal \\
\hline 39 & Sidodadi & 81 & Beringin & 123 & Sidoresmi & 163 & $\begin{array}{l}\text { Gunung Anyar } \\
\text { Tambak }\end{array}$ \\
\hline 40 & Simolawang & 82 & Lontar & 124 & Bendulmerisi & & \\
\hline 41 & Tambak Rejo & 83 & Sukomanunggal & & & & \\
\hline 42 & Embong Kaliasin & 84 & Tanjungsari & & & & \\
\hline
\end{tabular}


Informasi hasil survei wawancara rumah tangga terdiri pertama, informasi umum rumah tangga (pendapatan, jumlah anggota keluarga, pekerjaan, kepemilikan kendaraan dan lain-lain), kedua, informasi perjalanan setiap anggota keluarga berupa semua aktivitas perjalanan responden yang dilakukan sepanjang hari pada hari sebelumnya (satu hari sebelum wawancara) berupa waktu perjalanan, asal, tujuan dan maksud perjalanan serta moda transportasi yang digunakan.

Hasil dari survei wawancara rumah tangga diperoleh data asal - tujuan perjalanan penduduk kota Surabaya. Dengan data tersebut dapat diketahui jumlah produksi perjalanan (trip production) dan tarikan perjalanan (trip attraction) tiap zona lalu lintas.

Informasi asal tujuan perjalanan disusun sedemikian membentuk matrik asal tujuan perjalanan dengar ordo $163 \times$ x 163dan secara bersama-sama dengan matrik waktu perjalanan, sebagai variabel fungsi impedance, antar zona digunakan untuk proses kalibrasi model untuk mendapatkan model distribusi perjalanan (trip distribution model).

Proses kalibrasi meliputi1): (a) spesifikasi fungsi matematis untuk membentuk fungsi impedance $f\left(T_{i j}\right)$ yang mereplikakan bentuk dari trip-length frequency distribution hasil survai dan (b) menentukan parameterparameter dari fungsi ini sehingga mean trip length model lalu lintas sama dengan hasil survai lalu lintas.

Alur pikir $^{2}$ yang digunakan dalam pembuatan model dapat dilihat pada Gambar 3. Data survai Origin-Destination (O-D) dipakai untuk mengkalibrasi model sesuai dengan metode yang dipakai di mana dalam penelitian ini digunakan Fully Constraint/Doubly Constraint Gravity Model. Model gravity dalam penelitian ini dilakukan dengan fully/doubly contraint karena persamaan model dikekang oleh jumlah perjalanan baik pada sisi asal maupun tujuan perjalanan. Penjumlahan produksi perjalanan dari tiap-tiap zona asal harus sama dengan jumlah total trip production, dilain sisi, penjumlahan tarikan perjalanan dari tiap-tiap zona tujuan harus sama dengan jumlah total trip attraction ${ }^{6}$. Selanjutnya dari proses kalibrasi tersebut akan menghasilkan model distribusi perjalanan yang berisi pola asal tujuan perjalanan (O-D model).

Apakah model distribusi perjalanan terkalibrasi dapat digunakan sebagai alat bantu dalam memprediksi perjalanan di masa mendatang atau tidak diperlukan uji validasi model yang dapat memberikan gambaran tentang keakuratan model yang sudah terkalibrasi tersebut terhadap kondisi sebenarnya di lapangan. Proses validasi dapat dilakukan dengan metode analisa regresi untuk melihat seberapa jauh kemiripan hasil model dengan hasil survai. Apabila terbukti model yang terbentuk valid maka model itu dapat dipakai untuk memprakirakan pola perjalanan (O-D matrik) pada tahun-tahun yang akan datang. Apabila belum valid, maka proses harus diulang dari awal.

Persamaan Fully Constrained Gravity Model adalah sebagai berikut ${ }^{1)}$ :

$$
Q_{i j}=\frac{k_{i} k_{j} P_{i} A_{j}}{f\left(T_{i j}\right)}
$$

dimana

$$
\begin{aligned}
& k_{i}=\left\{\frac{\sum k_{j} A_{j}}{f\left(T_{i j}\right)}\right\}^{-1} \\
& k_{j}=\left\{\frac{\sum k_{i} P_{i}}{f\left(T_{i j}\right)}\right\}^{-1}
\end{aligned}
$$

Keterangan:

$$
\begin{array}{ll}
Q_{i j} & =\text { Perjalanan dari zona } \mathrm{i} \text { ke } \mathrm{j} \\
\mathrm{k}_{\mathrm{i}} & =\text { konstanta produksi zona } \mathrm{i} \\
\mathrm{k}_{\mathrm{j}} & =\text { konstanta tarikan zona } \mathrm{j} \\
\mathrm{P}_{\mathrm{i}} & =\text { produksi perjalanan dari zona } \mathrm{i} \\
\mathrm{A}_{\mathrm{j}} & =\text { tarikan perjalanan ke zona } \mathrm{j} \\
\mathrm{f}\left(\mathrm{T}_{\mathrm{ij}}\right) & =\text { fungsi impedance }
\end{array}
$$

Fungsi impedansi yang digunakan dalam pemodelan ini adalah 'exponential function' dengan persamaan sebagai berikut:

$$
f\left(T_{\mathrm{ij}}\right)=\exp \left(\beta \mathrm{T}_{\mathrm{ij}}\right)
$$




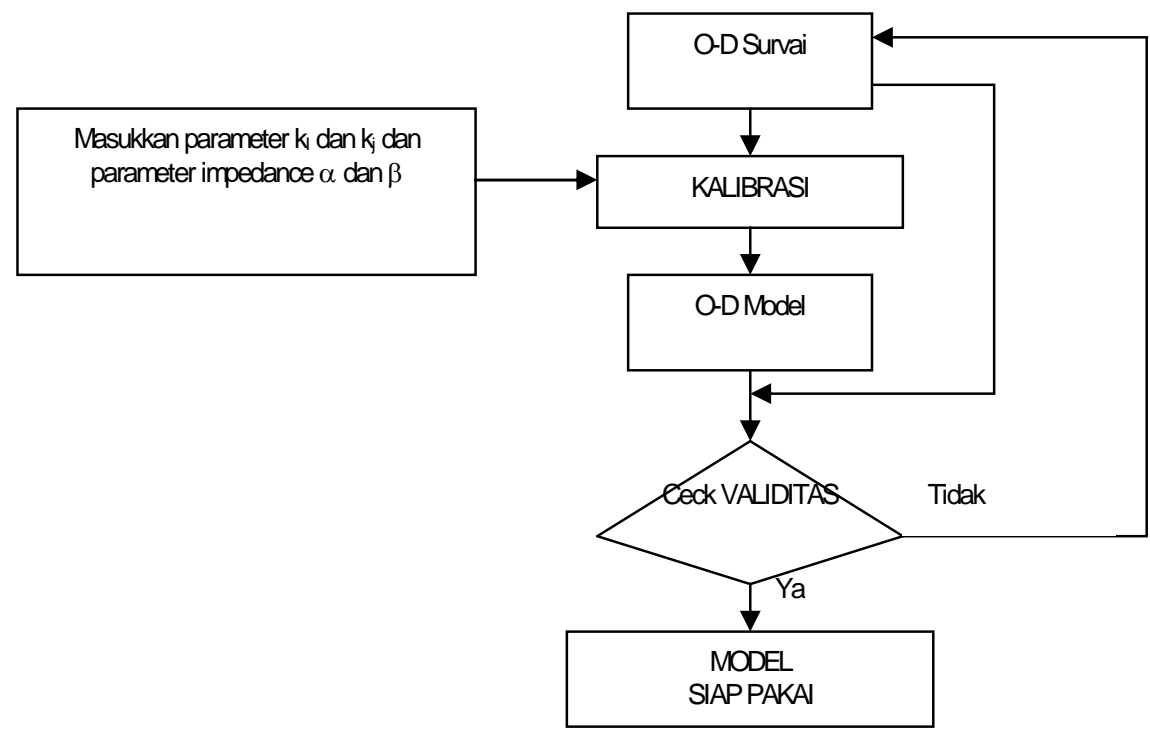

Gambar 3.

Alur Pemodelan

Fungsi impedance yang digunakan di dalam model gravity ini merupakan fungsi dari waktu perjalananantar zona (travel time). Dalam menentukan parameterparameter kalibrasi, proses dilakukan dengan cara iteratif sedemikian hingga diperoleh perbedaan antara mean trip length model dan survai sekitar $3 \%{ }^{1)}$.

\section{Kalibrasi model}

Prosedur paling sederhana dalam proses kalibrasi adalah menghitung demand model menggunakan nilai parameter $\beta$ pada suatu range tertentu dengan cara 'trial and error' sedemikian sehingga diperoleh nilai $\beta$ yang memenuhi ${ }^{1}$ :

$$
\left(\Sigma \Sigma \mathrm{Q}_{\mathrm{ij}}^{\prime} \mathrm{f}\left(\mathrm{T}_{\mathrm{ij}}\right)\right) / \Sigma \Sigma \mathrm{Q}_{\mathrm{ij}}^{\prime}=\left(\Sigma \Sigma \mathrm{Q}_{\mathrm{ij}} \mathrm{f}\left(\mathrm{T}_{\mathrm{ij}}\right)\right) / \Sigma \Sigma \mathrm{Q}_{\mathrm{ij}}
$$

Nilai parameter yang rendah menunjukkan mean trip length model relatif panjang dan nilai parameter yang tinggi menunjukkan mean trip length model relatif pendek.

Algoritma untuk memperkirakan nilai parameter model dan balancing factors (konstanta produksi dan tarikan) adalah sebagai berikut ${ }^{1)}$ :

Step 1: Pilih nilai awal parameter kalibrasi dan hitung balancing factors. Sebagai contoh, ambil $\beta=1$, dan gunakan semua $k_{j}^{\prime}$ dengan 1 . Balancing factors diselesaikan dengan prosedur iterasi, dengan mengasumsikan nilai baik $k_{i}$ maupun $k_{j}^{\prime}$. Nilai awal yang dipilih tidak penting karena balancing factors akan ditemukan. Untuk memulai proses iterasi, ausmsikan $\mathrm{k}_{\mathrm{j}}^{\prime}=1.0$ dan hitung $\mathrm{k}_{\mathrm{i}}$ dan selanjutnya $k_{i}$ dari iterasi ini digunakan sebagai input dalam menghitung $k_{j}^{\prime}$ pada iterasi berikutnya. Konvergensi dicapai jika nilai $k_{i}$ dalam iterasi ke-n sama dengan nilai $k_{i}$ dalam iterasi ke-(n-1).

Step 2: Masukkan balancing factors ke dalam persamaan model distribusi perjalanan (persamaan 1) dan hitung matrix model O-D.

Step 3: Hitung mean trip length dari semua perjalanan dalam matrix model O-D.

Step 4: Bandingkan mean trip length model dan survei dan sesuaikan parameter kalibrasi dengan menaikkan nilai parameternya jika mean trip length model terlalu besar, dan menurunkannya jika mean trip length model terlalu kecil.

Step 5: Pilih parameter kalibrasi lain dan ulangi step 1 sampai 4 sampai diperoleh kriteria kalibrasi yang memuaskan.

Model trip distribusi terkalibrasi diperoleh dengan melakukan iterasi sampai sepuluh kali untuk mencapai hasil yang konvergen. Data bangkitan perjalanan (trip generation) yang terdiri dari produksi perjalanan (trip production) dan tarikan perjalanan (triap attraction) masingmasing zona serta data besarnya jumlah perjalanan antar pasangan zona pada tahun dasar di daerah studi merupakan masukan utama disamping matrik waktu perjalanan antar zona yang digunakan sebagai impedance model.

Produksi dan tarikan perjalanan tiap-tiap zona perencanaan dengan menggunakan moda angkutan umum yang digunakan pada tahun 2011 berturut-turut dapat dilihat pada Gambar 4 . 


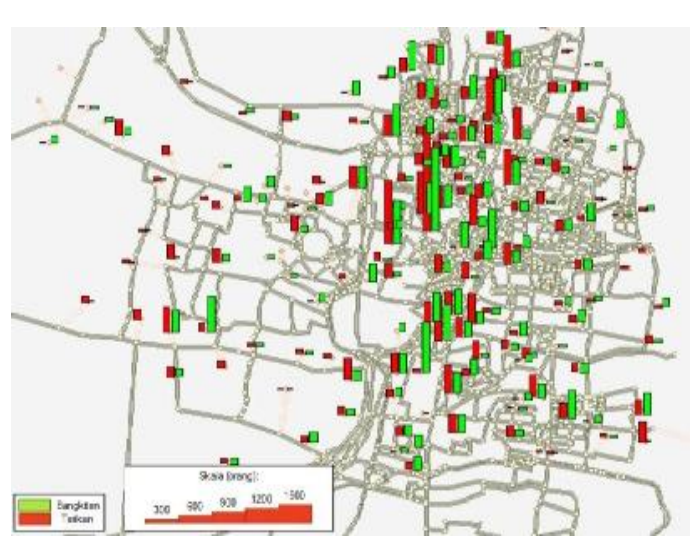

Gambar 4.

Bangkitan Perjalanan Moda Angkutan UmumTahun 2011

Fungsi impedansi yang terbentuk dari fungsi waktu perjalanan mempunyai faktor $\beta$ sebesar 0,063. Persamaan terkalibrasi tersebut adalah sebagai berikut:

$$
Q_{i j}=k_{i} k_{j} P_{i} A_{j} / d^{0,063}
$$

Di mana d adalah waktuperjalanan antar zona lalu lintas. Fungsi impedansi pada kondisi konvergen terjadi dengan perbedaan mean trip length antara model dan hasil survai dengan moda angkutan umum adalah sebesar $-5,4 \%$. Mean trip length (MTL) model distribusi perjalanan dengan angkutan umum adalah 17,04 menit dan hasil survai 18,02 menit.

Diagram histogram yang memberikan gambaran antara bentuk distribusi frekuensi mean trip length model dan hasil survai pada penggunaan moda angkutan umum berturut-turut dapat dilihat pada Gambar 5.

\section{HASIL DAN PEMBAHASAN}

Untuk melihat validitas model, digunakan metode sederhana dengan analisa regresi untuk melihat seberapa besar hubungan antara pola perjalanan model dengan kondisi lapangan (hasil survei). Asal tujuan perjalanan hasil survei (Qij) sebagai dependent variable $(\mathrm{Y})$ dan hasil pemodelan $\left(\mathrm{Qij}^{\wedge}\right)$ sebagai independent variable $(\mathrm{X})$, dan b adalah koefisien regresi,secara umum persamaan regresi adalah sebagai berikut ${ }^{4)}$ :

$$
\mathrm{Y}=\mathrm{a}+\mathrm{bX}
$$

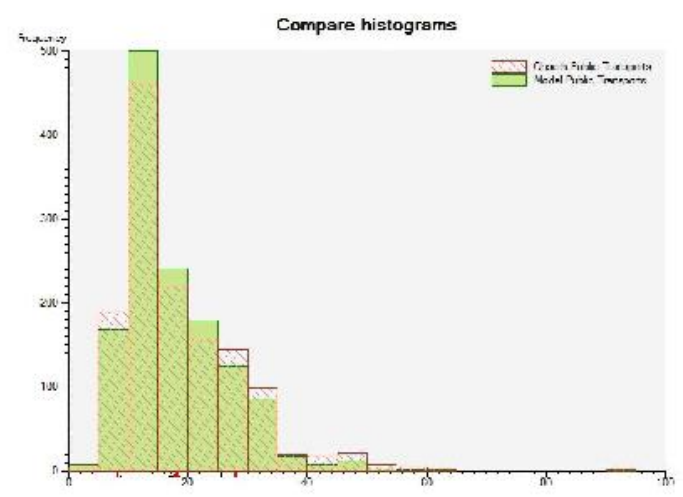

Gambar 5.

Perbandingan MTL model dan observasi $(H B P T)$

(HBPT: Home Base by Public Transport)

Dari analisa regresi dengan confidence level $95 \%$ diperoleh bahwa $\mathrm{R}^{2}$ adalah sebesar 0.88 Yang berarti kedekatan antara model dengan keadaan lapangan relatif bagus. Adapun hasil persamaan regresi tersebut adalah sebagai berikut:

$$
y=-0,00588 x+1,1158
$$

dimana :

$y$ : asal-tujuan perjalanan hasil survai

$x$ : asal-tujuan perjalanan hasil model

Untuk mempermudah secara visual perbedaan hasil model dengan data observasi dengan analisa regresi dapat dilihat pada Gambar 6.

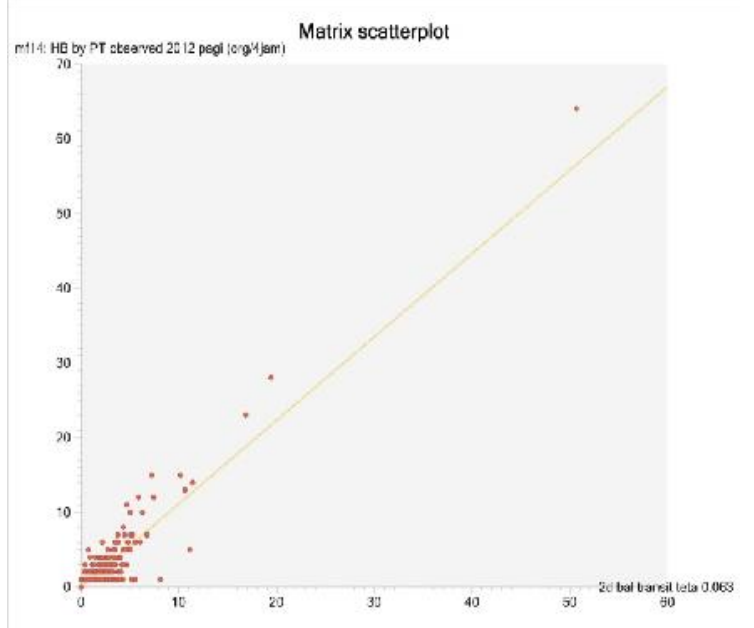

Gambar 6.

Hubungan model dan survei 


\section{Hasil pemodelan}

Hasil pengembangan model distribusi perjalanan di kota Surabaya dapat ditampilkan dalam gambar garis keinginan (desired lines) yang dapat memberikan informasi tentang besar kecilnya interaksi antar zona secara grafis. Garis keinginan untuk moda angkutan umum dapat dilihat pada Gambar 7.

Selanjutnya dengan memasukkan O-D matrix ke dalam sistem jaringan (proses pembebanan perjalanan) diperoleh data jumlah perjalanan pada setiap segmen jaringan. Informasi ini membantu dalam mengidentifikasi pada jaringan mana jumlah perjalanan yang diperkirakan naik angkutan umum masal cukup potensial. Hasil pembebanan perjalanan pada tahun dasar (2011) disajikan pada Gambar 8.

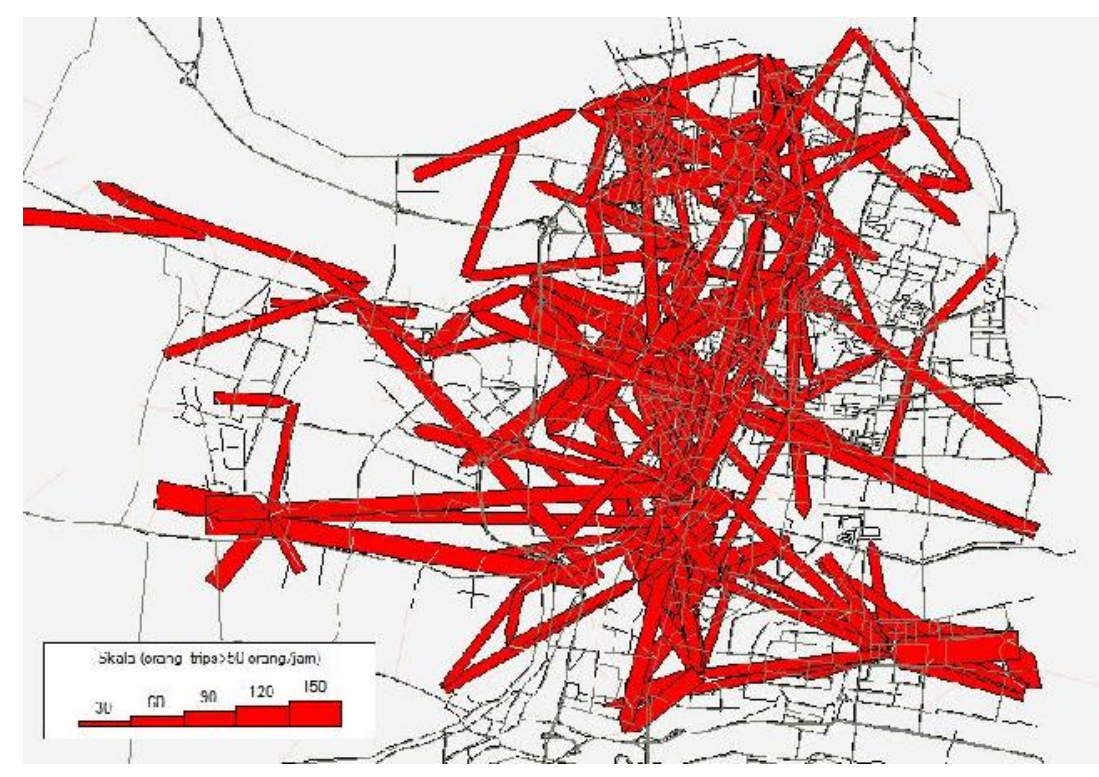

Gambar 7.

Desired Lines Moda Angkutan Umum Tahun Dasar 2011 (perjalanan orang/jam)

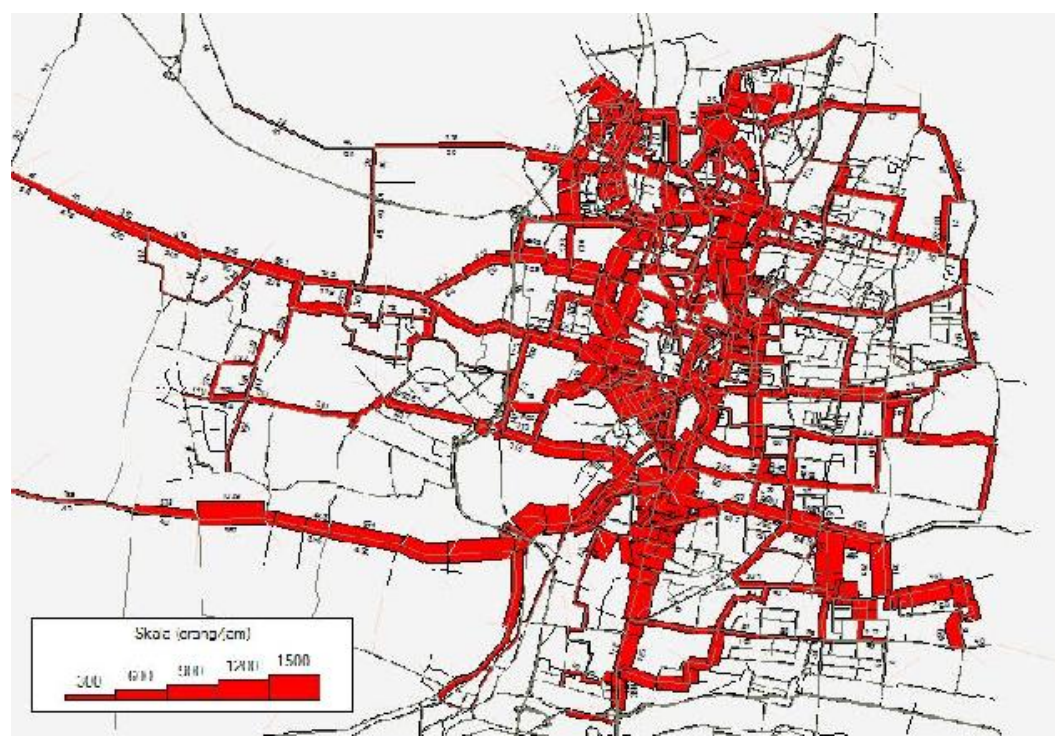

Gambar 8.

Pembebanan Perjalanan Dengan Angkutan Umum Tahun Dasar (Tahun 2011) 
Selanjutnya untuk memperkirakan besarnya perjalanan pada tahun 2030 digunakan data perkiraan produksi dan tarikan perjalanan pada tahun yang sama (tahun 2030). Besarnya produksi dan tarikan perjalanan di daerah studi pada tahun 2030 dapat dilihat pada Gambar 9. Dengan memasukkan bangkitan perjalanan tahun 2030 tersebut ke dalam model distribusi perjalanan tahun dasar yang telah divalidasi, dapat diperoleh prakiraan distribusi perjalanan tahun 2030. Pola perjalanan berupa garis keinginan di daerah studi tahun 2030 disajikan pada Gambar 10.
Dengan melakukan proses pembebanan (traffic assignment) terhadap distribusi perjalanan ke dalam sistem jaringan akan diperoleh jumlah perjalanan pada jaringan di tahun 2030. Pada proses pembebanan, dilakukan pada kondisi tarif jaringan feeder Rp. 4.000,- dan jaringan angkutan umum masal (monorel dan trem Rp. 10.000,-). Permintaan monorel diberi warna biru (Timur - Barat) dan trem warna kuning (Utara - Selatan). Perkiraan jumlah total perjalanan pada jaringan pada tahun 2030 dapat dilihat pada Gambar 11. dan Tabel 2.

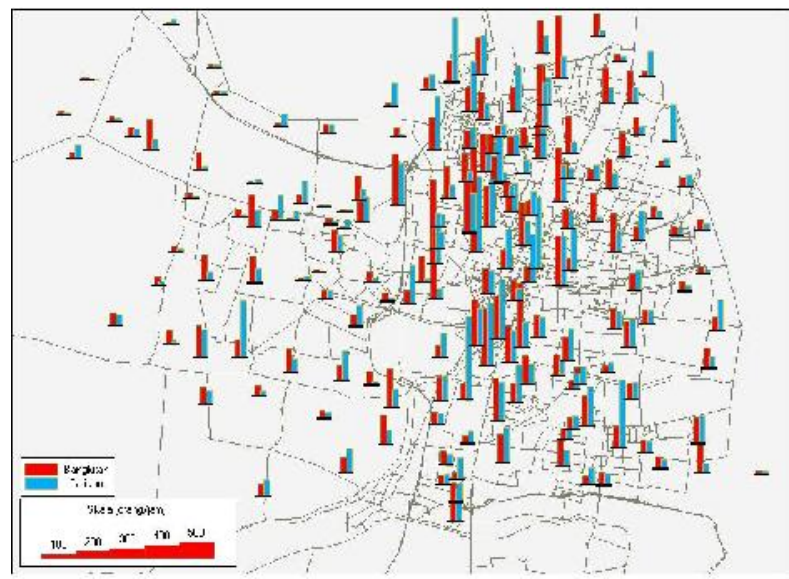

Gambar 9.

Bangkitan Perjalanan Tahun 2030

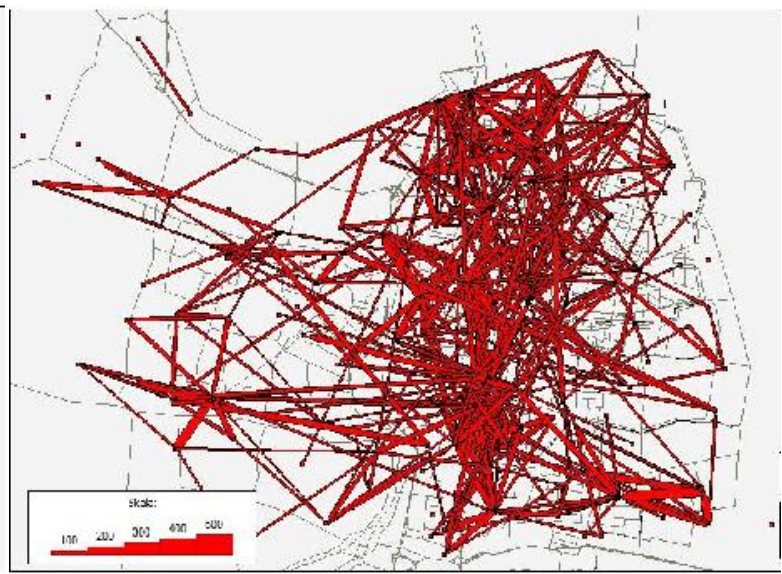

Gambar 10.

Desired Linesdi atas 50 trip Tahun Dasar 2030 (perjalan orang/jam

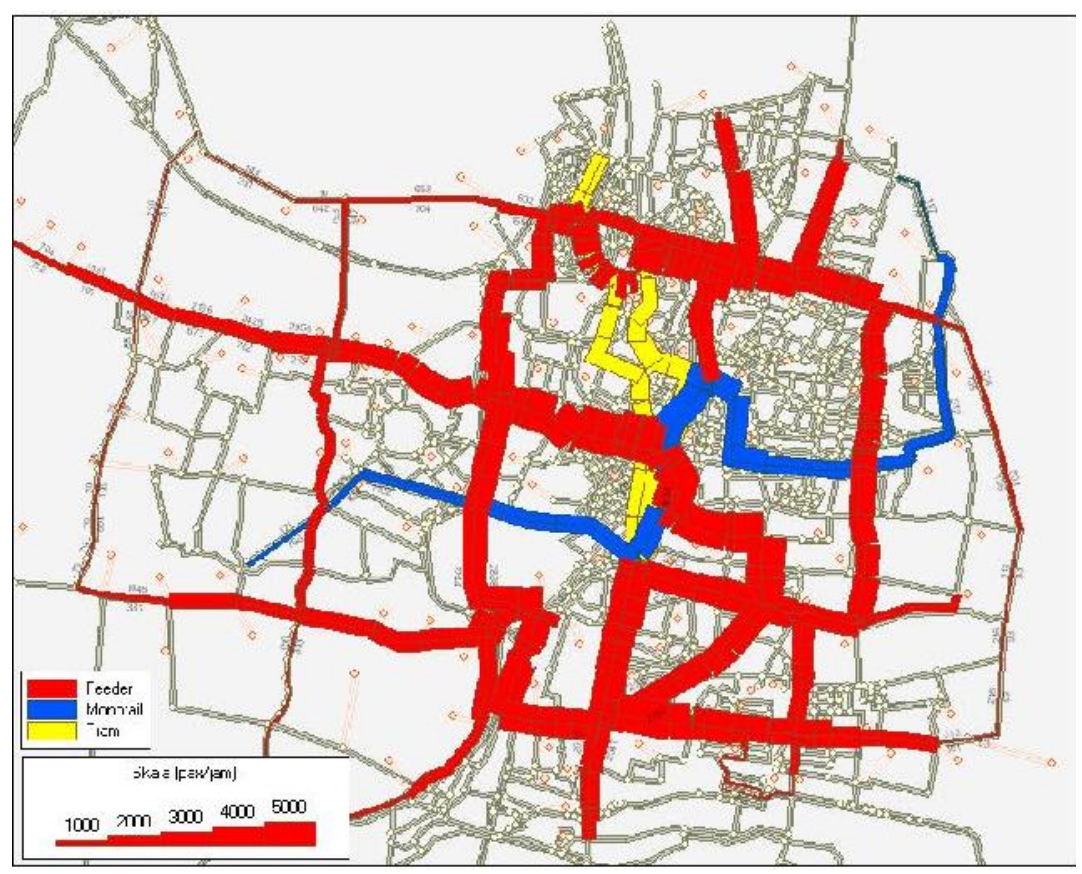

Gambar 11.

Pembebanan Perjalanan Tahun 2030 
Tabel 2.

Perkiraan Jumlah Penumpang Monorel dan Trem Tahun 2030 (pax/thn)

\begin{tabular}{cc}
\hline Tahun & $\begin{array}{c}\text { Bentuk Jaringan } \\
\text { Grid }\end{array}$ \\
\hline 2014 & 50.012 .877 \\
2015 & 50.973 .124 \\
2016 & 51.951 .808 \\
2017 & 52.949 .283 \\
2018 & 53.965 .909 \\
2019 & 55.002 .054 \\
2020 & 56.058 .094 \\
2021 & 57.134 .409 \\
2022 & 58.231 .390 \\
2023 & 59.349 .433 \\
2024 & 60.488 .942 \\
2025 & 61.650 .329 \\
2026 & 62.834 .016 \\
2027 & 64.040 .429 \\
2028 & 65.270 .005 \\
2029 & 66.523 .189 \\
2030 & 67.800 .434 \\
\hline
\end{tabular}

\section{SIMPULAN}

Berdasarkan hasil analisis dan pembahasan yang telah dilakukan pada penelitian ini dapat disimpulkan bahwa hasil kalibrasi model distribusi perjalanan menggunakan fungsi exponensial pada faktor impedansi dengan waktu perjalanan diperoleh parameter $\beta$ sebesar 0.063 memberikan perbedaan mean trip length antara model dan survai sebesar $-5,4 \%$.
Berdasarkan validasi model dengan menggunakan metode regresi memberikan gambaran bahwa model yang dikembangkan cukup baik dalam mereplikakan kondisi lapangan ditunjukkan oleh besarnya $R^{2}$ sebesar 0,88 sehingga model ini dapat dipakai dalam proses peramalan perjalanan penduduk Kota Surabaya di masa mendatang.

Koridor yang cukup potensial untuk diterapkan monoreldan trem sebagai angkutan umum masal di Kota Surabaya adalah koridor Waru - Jembatan merah (tanjung Perak), melalui ITS - Darmo Satelit, Rungkut Tunjungan, Tandes - Tunjungan dengan perkiraan jumlah penumpang total pada tahun 2030 sebesar 67.800 .434 penumpang/tahun untuk dua arah.

\section{UCAPAN TERIMA KASIH}

Diucapkan terima kasih kepada Dinas Perhubungan Surabaya dan pihak-pihak lain yang telah membantu data dan informasi sehingga tulisan ini dapat disusun.

\section{DAFTAR PUSTAKA}

1. Black, J.A., Urban Tranport Planning:"The Analysis of Travel Demand", Cromm Helm, London, 1981, hal. 61-104.

2. Badan Pusat Statistik Kota Surabaya,Surabaya Dalam Angka,2011

3. Dajan, Anto, Pengantar Metode Statistik Jilid I, LP3ES, 1993, hal $367-369$

4. Dinas PU Bina Marga dan Pematusan Kota Surabaya, 2011

5. http://www.icpsr.umich.edu/CrimeStat/files/C rimeStatChapter.14.pdf 